\title{
Consciousness Energy Healing Treatment Influenced the Physicochemical Properties of Zinc
}

\section{ISSN: 2640-9208}

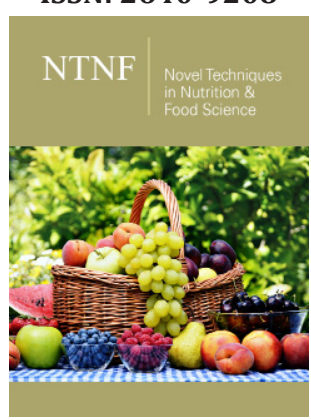

*Corresponding author: Snehasis Jana, Trivedi Science Research Laboratory Pvt. Ltd., Thane (W), India

Submission: 眥 August 10, 2019

Published: 漹August 26, 2019

Volume 4 - Issue 3

How to cite this article: Alice B, Mahendra Kumar T, Dahryn T, Gopal N, Snehasis J. Consciousness Energy Healing Treatment Influenced the Physicochemical Properties of Zinc. Nov Tech Nutri Food Sci. 4(3). NTNF.000586.2019.

DOI: 10.31031/NTNF.2019.04.000586

Copyright@ Alice Branton, This article is distributed under the terms of the Creative Commons Attribution 4.0 International License, which permits unrestricted use and redistribution provided that the original author and source are credited.

\author{
Alice $\mathrm{B}^{1}$, Mahendra Kumar $\mathrm{T}^{1}$, Dahryn $\mathrm{T}^{1}$, Gopal $\mathrm{N}^{1}$ and Snehasis $\mathrm{J}^{2 *}$ \\ ${ }^{1}$ Trivedi Global, Inc., USA \\ ${ }^{2}$ Trivedi Science Research Laboratory Pvt. Ltd., Thane (W), India
}

\begin{abstract}
Zinc is an essential trace element required by the body for many physiological functions. This study was executed to calculate the impact of the Trivedi Effect ${ }^{\circledR}$ on the physicochemical properties of zinc powder using modern analytical techniques. Zinc powder sample was divided into control and treated parts. Only the treated part received the Consciousness Energy Healing Treatment remotely by a renowned Biofield Energy Healer, Alice Branton. The powder XRD peak intensities of the treated zinc powder were significantly increased from $7.74 \%$ to $112.59 \%$ compared to the control sample. Likewise, the crystallite sizes of the treated zinc were significantly altered, ranging from $-42.43 \%$ to $84.50 \%$ compared with the control sample. Thus, the average crystallite size of the treated zinc powder was significantly decreased by $23.86 \%$ compared with the control sample. The particle size values in the treated zinc powder were significantly decreased by $28.10 \%\left(d_{10}\right), 97.98 \%\left(d_{50}\right), 97.43 \%\left(d_{90}\right)$, and $97.01 \%\{D(4,3)\}$ compared to the control sample. Therefore, the specific surface area of the treated zinc powder $\left(0.517 \mathrm{~m}^{2} / \mathrm{g}\right)$ was significantly increased by $120 \%$ compared with the control sample $\left(0.235 \mathrm{~m}^{2} / \mathrm{g}\right)$. The weight loss in total was significantly increased by $196.22 \%$; however, the residual amount was significantly increased by $46.18 \%$ in the treated zinc compared with the control sample. The $\mathrm{T}_{\max }$ of the $1^{\text {st }}$ and $2^{\text {nd }}$ peaks the Biofield Energy Treated zinc was significantly decreased by $5.61 \%$ and $10.22 \%$ compared to the control sample. The Trivedi Effect ${ }^{\circledR}$ might be responsible for a new polymorphic form of zinc, which would show more solubility and bioavailability compared with the control sample. The Trivedi Effect Treated zinc would be very useful to design better nutraceutical/pharmaceutical formulations that might offer better therapeutic response against parakeratosis, hypogeusia, dysosmia, anorexia, geophagia, hypogonadism, growth retardation, Wilson's disease, etc. Other than this, the treated zinc powder could be beneficial for the prenatal and postnatal development, enhancement of fertility, retino-protective, immunomodulatory, antioxidant, and putative antiviral activity in the body. The lowering of the thermal behavior it could be useful for the industrial applications for galvanization, anti-corrosion agent, preparations of alloys, chemical reactions, etc.
\end{abstract}

Keywords: Zinc; Consciousness energy healing treatment; The Trivedi effect ${ }^{\circledR}$; PXRD; Particle size; TGA/ DTG

\section{Introduction}

Zinc is a vital trace element required for many physiological functions in the body [1]. The natural source of zinc are animal meat, eggs, fish, shellfish, fowl, milk, wheat (germ and bran) and various seeds like poppy, sesame, alfalfa, beans, nuts, mustard, celery, almonds, whole grains, pumpkin seeds, sunflower seeds and blackcurrant [2,3]. Zinc resides in muscle, retina, prostate, bone, skin, kidney, liver, pancreas, and particularly in the red and white blood cells. The zinc ion is the second most abundant transition metal ion in the human body, play different roles in several biological processes. It is one of the fundamental parts of more than 100 enzymes (i.e., carbonic anhydrase, carboxypeptidase, etc.) and the proteins (i.e., metallothioneins), serves as structural ions in transcription factors, nucleic acid, and protein metabolism, coordinate amino acid chains, etc. [4-7]. Other than this, zinc has many pharmacological activities includes prenatal and postnatal development, enhancement of fertility, retino-protective, immunomodulatory, antioxidant, and putative antiviral in the body [1,6-8]. It also prevents the development of many deficiency disorders, i.e., parakeratosis, hypogeusia, dysosmia, anorexia, geophagia, hypogonadism, growth retardation, Wilson's disease, etc. [9-12]. Zinc, in combination with Liquorice (Glycyrrhiza glabra) reported with the increase leukocyte count [13]. Insufficient dietary intake, malabsorption, chronic liver, 
and renal disease, sickle cell disease, malignancy, acrodermatitis enteropathica, diabetes, and other chronic illnesses may be the cause of deficiency of zinc in the body [14]. It is used in different formulations for topical skin preparations, mouthwash, and shampoo. Zinc has other industrial applications for galvanization, anti-corrosion agent, preparations of alloys, chemical reactions, etc. [15].

Although zinc is essential for good quality of life, excess zinc can be harmful [16]. Zinc is soluble in acids and alkalies; insoluble in water [17]. The physicochemical properties always play a crucial role in its dissolution, absorption, and bioavailability profile of a pharmaceutical or nutraceutical compound [18]. Therefore, the researchers all over the world, paying attention to the improvement of the pharmaceutical and nutraceutical compounds. Similarly, it was experimentally observed that the Trivedi Effect ${ }^{\circledR}$ (Biofield Energy Healing Treatment) has a huge impact on various properties of pharmaceutical/nutraceutical compounds [19-22]. The Trivedi Effect ${ }^{\circledR}$ is a scientifically proven phenomenon in which a healer/expert can harness this intelligent energy and transfer it wherever on the planet via the possible mediation of neutrinos [23]. Every living organism generates this kind of unique energy by movement of charged particles in the body known as Biofield Energy, which is infinite, para-dimensional electromagnetic field. Biofield based energy therapies have significant outcomes against various disease [24]. National Institute of Health and National Center for Complementary and Alternative Medicine approved and comprised the energy therapy under complementary and Alternative Medicine category that has been accepted by most of the U.S. population $[25,26]$. The Trivedi Effect ${ }^{\circledR}$ also been widely reported scientifically with astounding experimental data altering the characteristic properties of the several non-living and living objects i.e. metals and ceramics [27,28], organic compounds [29,30], nutraceuticals/pharmaceuticals [31-33], microorganisms $[34,35]$, and crops [36,37]. Therefore, this study was performed to determine the impact of the Trivedi Effect ${ }^{\circledR}$ on the physicochemical properties of zinc using sophisticated analytical techniques.

\section{Results and Discussion}

\section{Powder X-ray diffraction (PXRD) analysis}

Table 1: Powder XRD data for the control and treated zinc.

\begin{tabular}{|c|c|c|c|c|c|c|c|c|}
\hline \multirow{2}{*}{ Entry No. } & \multicolumn{2}{|c|}{ Bragg Angle ( $\left.{ }^{\circ} \mathbf{2 \theta}\right)$} & \multicolumn{3}{|c|}{ Peak Intensity (\%) } & \multicolumn{3}{c|}{ Crystallite Size (G, nm) } \\
\cline { 2 - 10 } & Control & Treated & Control & Treated & \% Change* & Control & Treated & \% Change* \\
\hline 1 & 31.45 & 31.58 & 12.5 & 16.3 & 30.4 & 324 & 248 & -23.46 \\
\hline 2 & 34.08 & 34.14 & 9.8 & 17.2 & 75.51 & 329 & 607 & 84.5 \\
\hline 3 & 35.99 & 35.98 & 216 & 425 & 96.76 & 534 & 442 & -17.23 \\
\hline 4 & 38.73 & 38.75 & 143 & 304 & 112.59 & 571 & 436 & -23.64 \\
\hline 5 & 42.95 & 42.92 & 664 & 1107 & 66.72 & 673 & 431 & -35.96 \\
\hline
\end{tabular}

\section{Chemicals and reagents \\ The test sample zinc powder was purchased from Sigma Aldrich, USA, but the other chemicals were purchased in India.}

\section{Consciousness energy healing treatment strategies}

The test sample of zinc powder was divided into two parts. One part of zinc powder sample was not received the Biofield Energy Treatment called as a control sample. But, the other part of the test sample was received the Trivedi Effect ${ }^{\circledR}$-Consciousness Energy Healing Treatment remotely in standard laboratory conditions for 3 minutes by the famous Biofield Energy Healer, Alice Branton, USA, and known as the treated zinc powder. The control zinc powder was treated with a "sham" healer who is ignorant about the Biofield Energy Treatment. After that, both the samples were kept in sealed conditions and characterized using modern analytical techniques.

\section{Characterization}

The X-ray diffraction (PXRD) analysis of zinc powder sample was conducted with the help of Rigaku MiniFlex-II Desktop X-ray diffractometer (Japan) [38,39]. The crystals size was calculated using the Scherrer's formula (1)

$$
\mathrm{G}=\mathrm{k} \lambda / \beta \cos \theta
$$

Where G: crystallite size in $\mathrm{nm}, \mathrm{k}$ : equipment constant, $\lambda$ : radiation wavelength, $\beta$ : full width at half maximum, and $\theta$ : Bragg angle [40]. The particle size distribution (PSD) analysis was conducted with the help of Malvern Mastersizer 2000 (UK) using the wet method. Similarly, the thermogravimetric analysis (TGA) of zinc metal powder was performed with the help of TGA Q50 TA instruments [41,42]. The \% change in PXRD peak intensity, crystallite size, particle size, specific surface area, weight loss and the maximum thermal degradation temperature of the treated zinc powder was calculated compared with the control sample using the following equation 2 :

$$
\% \text { Change }=[\text { Treated }- \text { Control } / \text { Control }] \times 100
$$




\begin{tabular}{|c|c|c|c|c|c|c|c|c|}
\hline 6 & 54.04 & 54.03 & 120 & 194 & 61.67 & 727 & 460 & -36.73 \\
\hline 7 & 69.82 & 69.8 & 123 & 243 & 97.56 & 773 & 445 & -42.43 \\
\hline 8 & 70.4 & 70.4 & 82 & 163 & 98.78 & 785 & 472 & -39.87 \\
\hline 9 & 76.76 & 76.75 & 25.3 & 26.5 & 4.74 & 866 & 709 & -18.13 \\
\hline 10 & \multicolumn{8}{|c|}{ Average crystallite size } \\
\hline
\end{tabular}

*The percentage change in the peak intensity, and crystallite size of treated zinc compared to the control sample.

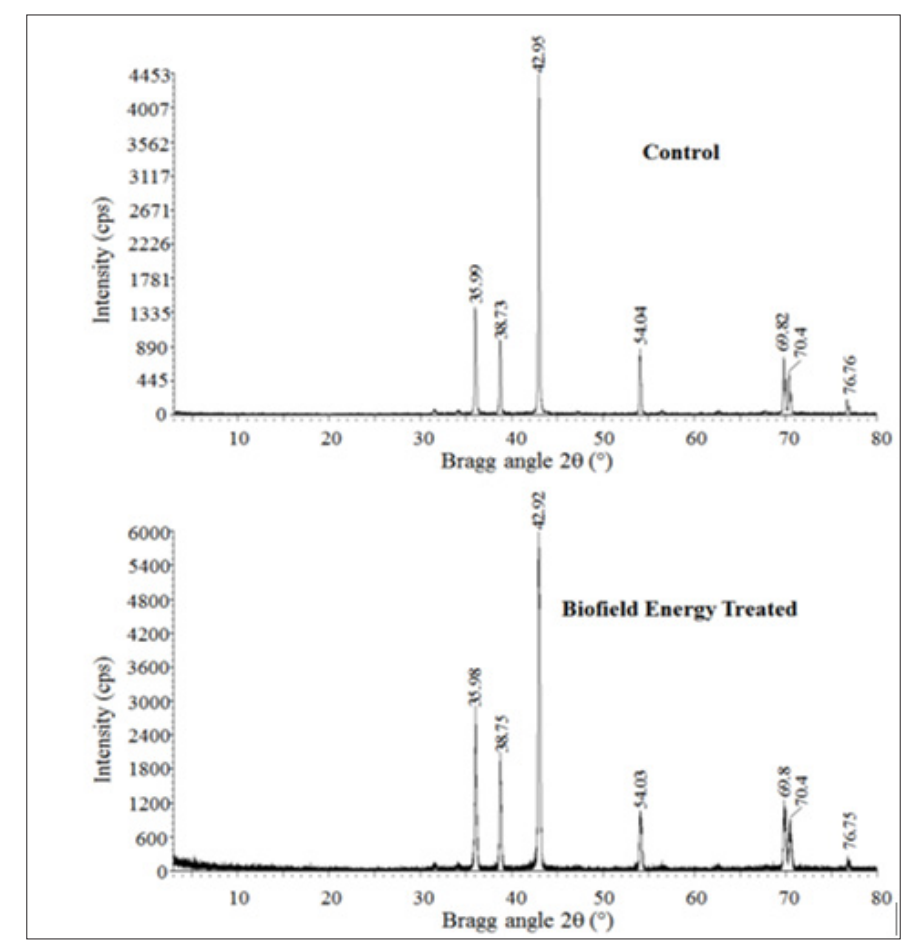

Figure 1: PXRD diffractograms of the control and treated zinc.

The PXRD analysis of the zinc powder samples were performed and the diffractograms showed sharp and prominent peaks at Bragg's angle (20) equal to $31.6^{\circ}, 34.1^{\circ}, 35.9^{\circ}, 38.6^{\circ}, 42.9^{\circ}, 54.0^{\circ}$, $69.8^{\circ}, 70.4^{\circ}$, and $76.8^{\circ}$ (Figure 1 ) indicated that both the samples were crystalline. The PXRD diffractograms of both the samples showed the highest peak intensity at $42.9^{\circ}$ (Table 1 ). All the peak intensities of the treated zinc powder were significantly increased from $7.74 \%$ to $112.59 \%$ compared to the control sample. The crystallite sizes of the treated zinc powder were significantly altered, ranging from $-42.43 \%$ to $84.50 \%$ compared to the control sample. Generally, the average crystallite size of the treated zinc $(472.22 \mathrm{~nm})$ was significantly decreased by $23.86 \%$ compared with the control sample $(620.22 \mathrm{~nm})$.

The variations in the crystallite sizes and peak intensities indicated the change of the crystal morphology of the Biofield Energy Treated zinc compared to the control sample. The peak intensity of each diffraction face on the crystalline compound alterations according to the crystal morphology [43] and alterations in the PXRD pattern provide the evidence of polymorphic changes $[44,45]$. Thus, it was concluded that the Trivedi Effect ${ }^{\circledR}$-Consciousness Energy Healing Treatment probably produced the new polymorphic form of zinc through the Biofield Energy via neutrino oscillation [23]. Different polymorphic forms of pharmaceuticals have the significant effects on the drug performances because of their thermodynamic and physicochemical properties like melting point, energy, stability, and especially solubility, are different from the original form [46,47]. Thus, it can be anticipated that the treated zinc would be better in designing pharmaceutical and/or nutraceutical formulations containing zinc.

\section{Particle size analysis (PSA)}

The particle size distribution analysis of both the powder samples was performed. The PSD curve of the treated zinc powder was meaningfully different compared to the control sample. One extra peak was observed in the case of the treated zinc compared to the control zinc (Figure 2). The particle size values in the Biofield Energy Treated zinc were significantly decreased at $d_{10}, d_{50}, d_{90}$, and D $(4,3)$ by $28.10 \%, 97.98 \%, 97.43 \%$, and $97.01 \%$, respectively compared to the control sample (Table 2). The specific surface area of Biofield Energy Treated zinc powder $\left(0.517 \mathrm{~m}^{2} / \mathrm{g}\right)$ was significantly increased by $120 \%$ compared with the control sample $\left(0.235 \mathrm{~m}^{2} / \mathrm{g}\right)$. Hence, it can be assumed that the Biofield Energy Treatment might be acting as an external force for reducing the particle size; hence increased the surface area of zinc. Reducing the particle size of pharmaceutical compounds increase the surface area and improve the solubility, dissolution rate, and bioavailability in the physiological system $[41,48]$. Zinc is insoluble in water [17]. Thus, it is assumed that the treated zinc might offer better bioavailability compared with the control sample. 


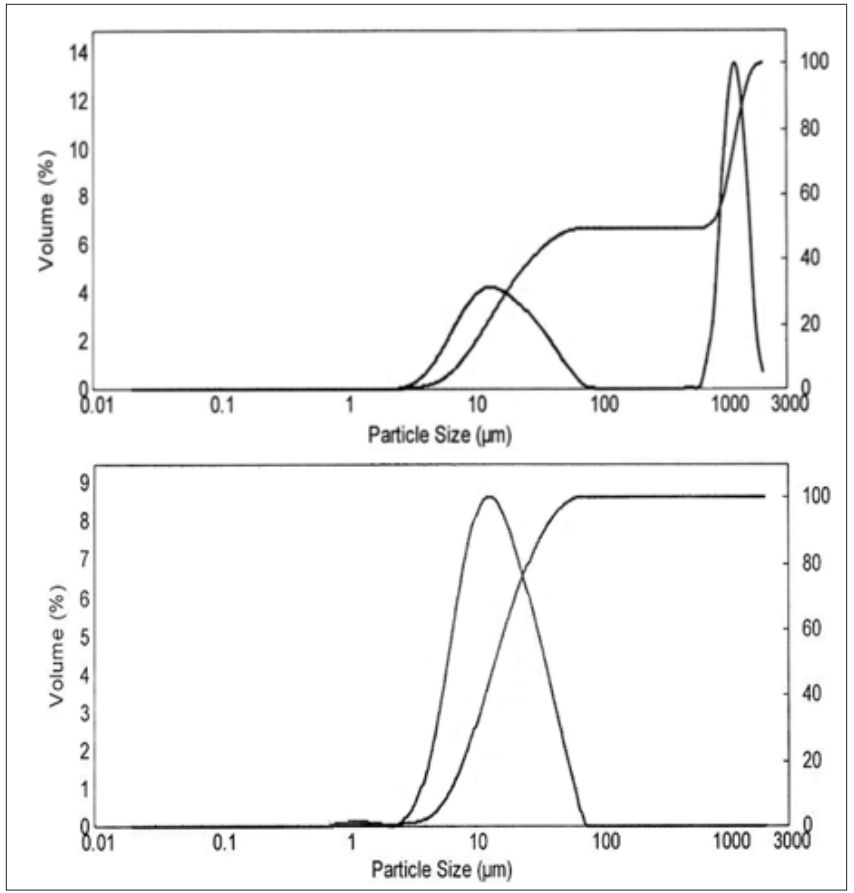

Figure 2: Particle size distribution curve of the control and biofield energy treated zinc.

Table 2: The particle size distribution of the control and treated zinc.

\begin{tabular}{|c|c|c|c|c|c|}
\hline Parameters & $d_{10}(\mu \mathrm{m})$ & $d_{50}(\mu \mathrm{m})$ & $d_{90}(\mu \mathrm{m})$ & $D(4,3)(\mu \mathrm{m})$ & $\operatorname{SSA}\left(\mathrm{m}^{2} / \mathrm{g}\right)$ \\
\hline Control & 8.79 & 720.6 & 1405.98 & 611.76 & 0.235 \\
\hline Biofield Treated & 6.32 & 14.56 & 36.09 & 18 & 0.517 \\
\hline Percent change* (\%) & -28.1 & -97.98 & -97.43 & -97.01 & 120 \\
\hline
\end{tabular}

* The percentage change in the particle size distribution and surface area of the treated zinc compared to the control sample.

Thermal gravimetric analysis (TGA) / Differential thermogravimetric analysis (DTG)

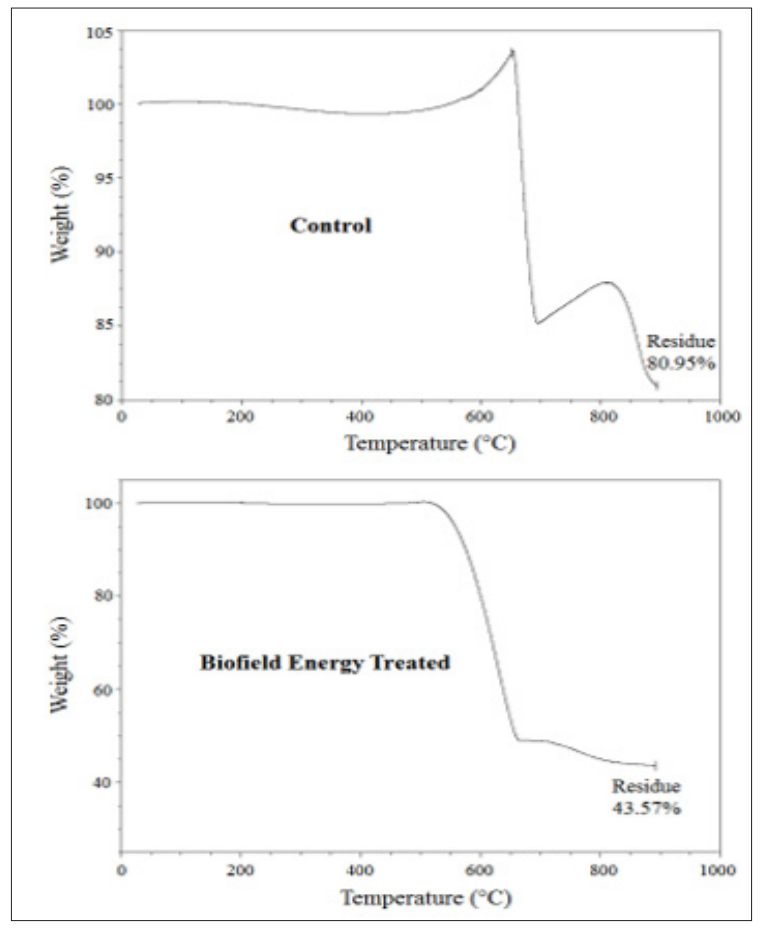

Figure 3: TGA thermograms of the control and treated zinc. 
The TGA thermograms of both the samples showed two steps of thermal degradation process (Figure 3). The total weight loss in Biofield Energy Treated zinc was significantly increased by $196.22 \%$ compared with the control sample (Table 3). Therefore, the residue amount was significantly decreased by $46.18 \%$ in the Biofield Energy Treated zinc compared to the control sample (Table 3). The DTG thermograms of the control and Biofield Energy Treated zinc powder also exhibited two peaks (Figure 4). The $\mathrm{T}_{\max }$ of $1^{\text {st }}$ and $2^{\text {nd }}$ peaks in the Biofield Energy Treated zinc was significantly decreased by $5.61 \%$ and $10.22 \%$ compared with the control sample (Table 3). Overall, TGA/DTG revealed that the thermal stability of the Biofield Energy Treated zinc was significantly decreased compared with the control sample.

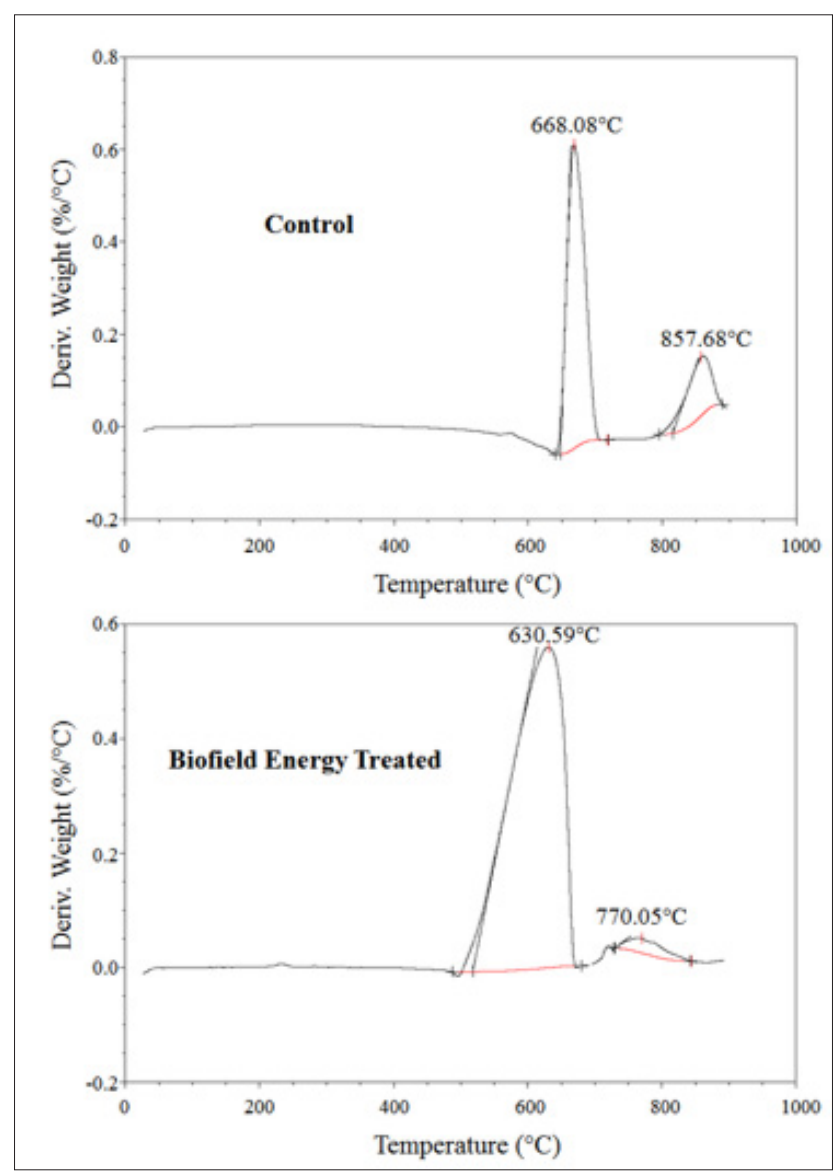

Figure 4: DTG thermograms of the control and treated zinc.

Table 3: TGA/DTG data of the control and treated zinc.

\begin{tabular}{|c|c|c|c|c|}
\hline \multirow{2}{*}{ Sample } & \multicolumn{2}{|c|}{ TGA } & \multicolumn{2}{c|}{ DTG; T $_{\max }\left({ }^{\circ} \mathbf{C}\right)$} \\
\cline { 2 - 5 } & Total weight loss (\%) & Residue \% & $\mathbf{1}^{\text {st }}$ Peak & 2 ${ }^{\text {nd }}$ Peak \\
\hline Control & 19.05 & 80.95 & 668.08 & 770.05 \\
\hline Biofield Energy Treated & 56.43 & 43.57 & 630.59 & -10.22 \\
\hline \% Change
\end{tabular}

${ }^{*}$ denotes the percentage change of the treated zinc compared with the control sample.

\section{Conclusions}

The Trivedi Effect ${ }^{\circledR}$-Consciousness Energy Healing Treatment showed significant effects on the physicochemical properties of zinc powder. The PXRD peak intensities of the Biofield Energy Treated zinc were significantly increased from $7.74 \%$ to $112.59 \%$ compared to the control sample. Similarly, the crystallite sizes of the Biofield Energy Treated zinc were significantly altered, ranging from $-42.43 \%$ to $84.50 \%$ compared to the control sample. However, the average crystallite size of the Biofield Energy Treated zinc was significantly decreased by $23.86 \%$ compared to the control zinc. The particle size values in the Biofield Energy Treated zinc powder were significantly decreased by $28.10 \%\left(d_{10}\right), 97.98 \%\left(d_{50}\right), 97.43 \%$ $\left(d_{90}\right)$, and $97.01 \%\{D(4,3)\}$ compared to the control sample. Thus, the specific surface area of the Biofield Energy Treated zinc powder was significantly increased by $120 \%$ compared with the control sample. The total weight loss was significantly increased by 196.22\%; however, the residual amount was significantly increased by $46.18 \%$ in the treated zinc compared with the control sample. 
The $\mathrm{T}_{\max }$ of $1^{\text {st }}$ and $2^{\text {nd }}$ peaks the Biofield Energy Treated zinc was significantly decreased by $5.61 \%$ and $10.22 \%$ compared with the control sample. The Consciousness Energy Healing Treatment might be responsible for a new polymorphic form of zinc, which would be more soluble, and bioavailable compared with the control sample. The Trivedi Effect Treated zinc would be very useful to design better nutraceutical/pharmaceutical formulations that might offer better therapeutic response against parakeratosis, hypogeusia, dysosmia, anorexia, geophagia, hypogonadism, growth retardation, Wilson's disease, etc. Other than this, the Biofield Energy Treated zinc powder could be beneficial for the prenatal and postnatal development, enhancement of fertility, retino-protective, immunomodulatory, antioxidant, and putative antiviral activity in the body. The lowering of the thermal behavior it could be useful for the industrial applications for galvanization, anti-corrosion agent, preparations of alloys, chemical reactions, etc.

\section{Acknowledgements}

The authors are grateful to Central Leather Research Institute, SIPRA Lab Ltd, Trivedi Science, Trivedi Global, Inc, Trivedi Testimonials, and Trivedi Master Wellness for their assistance and support during this work.

\section{References}

1. Hambidge KM, Krebs NF (2007) Zinc deficiency: A special challenge. J Nutr 137(4): 1101-1105

2. Ensminger AH, Konlande JE (1993) Foods \& Nutrition Encyclopedia $\left(2^{\text {nd }}\right.$ edn), CRC Press, Boca Raton, Florida, USA, pp. 2368-2369.

3. Zinc content of selected foods per common measure (2018) USDA National Nutrient Database for Standard Reference, Release 20. United States Department of Agriculture.

4. Laura P, Lothar R, Hajo H (2010) The essential toxin: Impact of zinc on human health. Int J Environ Res Public Health 7(4): 1342-1365.

5. Erik GB, Mikko H, Tore B, Tomas B, Olle E (2009) Molecular dynamics study of zinc binding to cysteines in a peptide mimic of the alcohol dehydrogenase structural zinc site. Phys Chem Chem Phys 11(6): 975983.

6. Ronconi L, Sadler PJ (2008) Applications of heteronuclear NMR spectroscopy in biological and medicinal inorganic chemistry. Coordn Chem Rev 252(21-22): 2239-2277.

7. Berg JM, Shi Y (1996) The galvanization of biology: A growing appreciation for the roles of zinc. Science 271(5252): 1081-1085.

8. Higdon JV, Ho E (2005) In: Gielen M, Tiekink ERT (Eds.), Metallo therapeutic drugs and metal-based diagnostic agents: The use of metals in medicine. Wiley-VCH, Weinheim, Germany, p. 237.

9. Brewer GJ (2001) Zinc acetate for the treatment of Wilson's disease. Expert Opin Pharmacother 2(9): 1473-1477.

10. Prasad AS (1979) Clinical, biochemical, and pharmacological role of zinc. Ann Rev Pharmacol Toxicol 19: 393-426.

11. Supuran CT (2008) Carbonic anhydrases: Novel therapeutic applications for inhibitors and activators. Nat Rev Drug Discov 7(2): 168-181.

12. Elmes ME (1975) Letter: Zinc in human medicine. Lancet 306(7934): 549.

13. Mazumder PM, Pattnayak S, Parvani H, Sasmal D, Rathinavelusamy P (2012) Evaluation of immunomodulatory activity of Glycyrhiza glabra L roots in combination with zing. Asian Pac J Trop Biomed 2(1): S15-S20.

14. Prasad AS (2003) Zinc deficiency. BMJ 326(7386): 409-410.
15. https://en.wikipedia.org/wiki/Zinc

16. Fosmire GJ (1990) Zinc toxicity. Am J Clin Nutr 51(2): 225-227.

17. https://pubchem.ncbi.nlm.nih.gov/compound/zinc

18. Chereson R (2009) Bioavailability, bioequivalence, and drug selection. In: Makoid CM, Vuchetich PJ, Banakar UV (Eds.) Basic pharmacokinetics ( $1^{\text {st }}$ edn), Pharmaceutical Press, London, UK.

19. Trivedi MK, Branton A, Trivedi D, Nayak G, Afaganis AE, et al. (2017) An Impact of energy of consciousness (the Trivedi Effect ${ }^{\circledR}$ ) on the physicochemical, thermal, structural, and behavioral properties of magnesium gluconate. Biomedical Sciences 3(2): 42-54.

20. Trivedi MK, Branton A, Trivedi D, Nayak G, Lee AC, et al. (2016) Impact of biofield energy treated herb mineral formulation (the Trivedi Effect $\left.{ }^{\circledR}\right)$ on mouse dendritic and splenocyte cells for modulation of proinflammatory cytokines. International Journal of Immunology 4(5): 3545 .

21. Trivedi MK, Branton A, Trivedi D, Nayak G, Wellborn BD, et al. (2017) Effect of the energy of consciousness (the Trivedi Effect ${ }^{\circledR}$ ) on the structural properties and isotopic abundance ratio of magnesium gluconate using LC-MS and NMR spectroscopy. Advances in Biochemistry 5(1): 7-15.

22. Branton A, Jana S (2017) Effect of the biofield energy healing treatment on the pharmacokinetics of 25-hydroxyvitamin $\mathrm{D}_{3}\left[25(\mathrm{OH}) \mathrm{D}_{3}\right]$ in rats after a single oral dose of vitamin $\mathrm{D}_{3}$. American Journal of Pharmacology and Phyto therapy 2: 11-18.

23. Trivedi MK, Mohan TRR (2016) Biofield energy signals, energy transmission and neutrinos. American Journal of Modern Physics 5(6): 172-176.

24. Rubik B, Muehsam D, Hammerschlag R, Jain S (2015) Biofield science and healing: History, terminology, and concepts. Glob Adv Health Med 4: 8-14.

25. Barnes PM, Bloom B, Nahin RL (2008) Complementary and alternative medicine use among adults and children: United States, 2007. Natl Health Stat Report 12: 1-23.

26. Koithan M (2009) Introducing complementary and alternative therapies. J Nurse Pract 5(1): 18-20.

27. Dabhade VV, Tallapragada RMR, Trivedi MK (2009) Effect of external energy on the atomic, crystalline, and powder characteristics of antimony and bismuth powders. Bulletin of Materials Science 32(5): 471-479.

28. Trivedi MK, Tallapragada RM (2009) Effect of super consciousness external energy on the atomic, crystalline and powder characteristics of "carbon allotrope powders". Materials Research Innovations 13(4): 473-480.

29. Trivedi MK, Branton A, Trivedi D, Nayak G, Sethi KK, et al. (2016) Determination of isotopic abundance ratio of biofield energy treated 1,4-dichlorobenzene using gas chromatography-mass spectrometry (GC-MS). Modern Chemistry 4(3): 30-37.

30. Trivedi MK, Branton A, Trivedi D, Nayak G, Panda P, et al. (2016) Gas chromatography-mass spectrometric analysis of isotopic abundance of ${ }^{13} \mathrm{C},{ }^{2} \mathrm{H}$, and ${ }^{18} \mathrm{O}$ in biofield energy treated $p$-tertiary butylphenol (PTBP). American Journal of Chemical Engineering 4(4): 78-86.

31. Branton A, Jana S (2017) The influence of energy of consciousness healing treatment on low bioavailable resveratrol in male Sprague Dawley rats. International Journal of Clinical and Developmental Anatomy 3(3): 9-15.

32. Branton A, Jana S (2017) The use of novel and unique biofield energy healing treatment for the improvement of poorly bioavailable compound, berberine in male Sprague Dawley rats. American Journal of Clinical and Experimental Medicine 5(4): 138-144.

33. Trivedi MK, Patil S, Shettigar H, Bairwa K, Jana S (2015) Effect of biofield treatment on spectral properties of paracetamol and piroxicam. Chem Sci J 6: 98. 
34. Trivedi MK, Branton A, Trivedi D, Nayak G, Mondal SC, et al. (2015) Antimicrobial sensitivity, biochemical characteristics and bio typing of Staphylococcus saprophyticus: An impact of biofield energy treatment. J Women's Health Care 4(6): 271.

35. Trivedi MK, Branton A, Trivedi D, Nayak G, Shettigar H, et al. (2015) Antibiogram of multidrug-resistant isolates of Pseudomonas aeruginosa after biofield treatment. J Infect Dis Ther 3: 244.

36. Trivedi MK, Branton A, Trivedi D, Nayak G, Gangwar M, et al. (2015) Agronomic characteristics, growth analysis, and yield response of biofield treated mustard, cowpea, horse gram, and groundnuts. International Journal of Genetics and Genomics. 3(6): 74-80.

37. Trivedi MK, Branton A, Trivedi D, Nayak G, Mondal SC, et al. (2015) Evaluation of plant growth, yield and yield attributes of biofield energy treated Mustard (Brassica juncea) and Chickpea (Cicer arietinum) Seeds. Agriculture, Forestry and Fisheries 4(6): 291-295.

38. (1997) Desktop X-ray diffractometer "MiniFlex+". The Rigaku Journal 14(1): 29-36.

39. Zhang T, Paluch K, Scalabrino G, Frankish N, Healy AM, et al. (2015) Molecular structure studies of (1S,2S)-2-benzyl-2,3-dihydro-2(1Hinden-2-yl)-1H-inden-1-ol. J Mol Struct 1083: 286-299.

40. Langford JI, Wilson AJC (1978) Scherrer after sixty years: A survey and some new results in the determination of crystallite size. J Appl Cryst 11: 102-113.

41. Trivedi MK, Sethi KK, Panda P, Jana S (2017) A comprehensive physicochemical, thermal, and spectroscopic characterization of zinc (II) chloride using X-ray diffraction, particle size distribution, differential scanning calorimetry, thermogravimetric analysis/ differential thermogravimetric analysis, ultraviolet-visible, and Fourier transform-infrared spectroscopy. Int J Pharm Investig 7(1): 33-40.

42. Trivedi MK, Sethi KK, Panda P, Jana S (2017) Physicochemical, thermal and spectroscopic characterization of sodium selenate using XRD, PSD, DSC, TGA/DTG, UV-vis, and FT-IR. Marmara Pharmaceutical Journal 21/2: 311-318.

43. Inoue M, Hirasawa I (2013) The relationship between crystal morphology and XRD peak intensity on $\mathrm{CaSO}_{4} \cdot 2 \mathrm{H}_{2} \mathrm{O}$. J Crystal Growth 380: 169-175.

44. Raza K, Kumar P, Ratan S, Malik R, Arora S (2014) Polymorphism: The phenomenon affecting the performance of drugs. SOJ Pharm Pharm Sci 1(2): 10 .

45. Brittain HG (2009) Polymorphism in pharmaceutical solids in drugs and pharmaceutical sciences ( $2^{\text {nd }}$ edn), Informa Healthcare USA, New York, USA, Volume 192.

46. Censi R, Martino PD (2015) Polymorph impact on the bioavailability and stability of poorly soluble drugs. Molecules 20(10): 18759-18776.

47. Blagden N, Matas M, Gavan PT, York P (2007) Crystal engineering of active pharmaceutical ingredients to improve solubility and dissolution rates. Adv Drug Deliv Rev 59(7): 617-630.

48. Zhao Z, Xie M, Li Y, Chen A, Li G, et al. (2015) Formation of curcumin nanoparticles via solution-enhanced dispersion by supercritical $\mathrm{CO}_{2}$. Int J Nanomedicine 10: 3171-3181. 